\title{
Margaret McCartney: Direct patient care should be rewarded and cherished
}

\author{
Margaret McCartney general practitioner
}

Glasgow

You would be forgiven for thinking that all doctors get paid roughly the same, pro rata, for the same work. But some recent revelations have contested this belief.

One such revelation was the leaking of a letter by a public health consultant showing wide disparities in earnings among GPs: some earn well below the average of $£ 100000$ for a full time GP in Scotland, but others earn more than $£ 300000 .{ }^{1}$ Sure, some people are part time, others are full time, others do a lot of on-call, and others do not. But this range is troubling.

What bothers me most about such pay disparities is the existence of a wide, inbuilt gap in doctors' pay, where obscene amounts of money are paid to some GPs and consultants at the top end. These figures are simply too much to justify to taxpayers or to anyone else. What's more, it's possible to earn this much as a doctor only by doing less of the very thing that's most important, and for which we receive the most training-direct patient care.

GPs who own chains of surgeries, and who employ doctors to do the core work at lower cost, may boost their own take home drawings. But they do so by paying others less than themselves, to do the most important work. Consultants at the top end of the scale may sit on so many committees that they see far fewer patients than their colleagues. These colleagues may then end up doing more work to cover these clinics, while the consultants on committees boost their own CVs with less stressful and less legally risky work.

GPs who own chains of surgeries may boost their own take home drawings-by paying others less than themselves, to do the most important work

Direct patient care should be cherished and rewarded. People who do on-call or night shifts should be paid well for doing so, especially given the association with increased mortality. ${ }^{23}$
Doctors who take on extra responsibilities should have their pay banded for doing so-but, if they also do less clinical work as a consequence, their overall pay should be reviewed accordingly.

We should be transparent about pay, including for people in corporate positions in the NHS. GPs already have a contractual obligation to publish average earnings, ${ }^{4}$ which can disguise huge disparities, and these declarations are for earnings before employer pension contributions, which makes it hard to determine what GPs actually take home. We need greater transparency around what these earnings mean in terms of take home pay.

None of this would sort out all of the problems with the gap in pay between the highest earning doctors and the rest. But it would at least help us to see where the issues are.

Competing interests: See www.bmj.com/about-bmj/freelance-contributors/margaretmccartney.

Provenance and peer review: Commissioned; not externally peer reviewed.

Follow Margaret on Twitter, @mgtmccartney

1 Herald view: an anomaly of GP pay in the poorest areas. Sunday Herald 9 Feb 2017. www.heraldscotland.com/opinion/15983491.Herald_View_An_anomaly_of_GP_pay_ in_our_poorest_areas/.

2 Gu F, Han J, Laden F, etal . Total and cause-specific mortality of U.S. nurses working rotating night shifts. Am J Prev Med 2015;48:241-52.

10.1016/j.amepre.2014.10.018 25576495

3 Vetter C, Devore EE, Wegrzyn LR, etal. Association between rotating night shift work and risk of coronary heart disease among women. JAMA 2016;315:1726-34. 10.1001/jama.2016.4454. 27115377

4 BMA. Focus on publication of GP net earnings. 11 Aug 2016. https://www.bma.org.uk/ advice/employment/gp-practices/gps-and-staff/publication-of-gp-net-earnings.

Published by the BMJ Publishing Group Limited. For permission to use (where not already granted under a licence) please go to http://group.bmj.com/group/rights-licensing/ permissions 